Ingrid K. Jakobsen

UiT The Artic University of Norway

DOI: http://dx.doi.org/10.5617/adno.6248

\title{
Inspired by image: A multimodal analysis of 10th grade English school-leaving written examinations set in Norway (2014-2018)
}

\begin{abstract}
What role does multimodality play in assessment in the English subject in Norway? This article focuses on final written examinations from 2014 to 2018 and investigates the multimodal literacy skills that examinations invite lower secondary school students to demonstrate. Examinations in the English subject are digital and technically open to a rich multimodal practice. Analysis in this article finds that the texts to be read in examinations are carefully designed multimodal texts, with plentiful use of visual aspects of writing and with images that add significantly to the creation of complex cohesive ensembles. When it comes to the examination tasks, however, the opportunity for the students' multimodal output is limited and ambiguous. In sum, there is an imbalance between input and output.
\end{abstract}

Keywords: multimodal literacy, multimodal texts, English, assessment, lower secondary school

Inspirert av bilder: En multimodal analyse av sentralt gitt skriftlig eksamen for 10. trinn i engelsk i Norge fra 2014 til 2018

\section{Sammendrag}

Hvilken rolle spiller multimodalitet i engelskfagets vurderingspraksis i Norge? Denne artikkelen fokuserer på avsluttende skriftlig eksamen fra 2014 til 2018, og undersøker hvilken multimodal literacy (tekstkyndighet) eksamen legger opp til at ungdomsskoleelever får vise fram. Eksamen i faget er digital og teknisk sett åpner den for en rik multimodal praksis. Analysen i artikkelen viser at eksamenstekstene elevene leser er nøye designede multimodale tekster, med rikelig bruk av visuelle aspekter ved skrift, og med bilder som bidrar til komplekse, helhetlige, sammensatte tekster. Når det gjelder eksamensoppgavene derimot, er elevens 
mulighet til å uttrykke seg multimodalt både begrenset og tvetydig. Alt i alt er det en ubalanse mellom det som skal leses og det som skal skrives til eksamen.

Nøkkelord: multimodal literacy, sammensatte tekster, engelsk, vurdering, ungdomstrinn

\section{Introduction}

This article investigates the role of multimodality in the national written schoolleaving examinations in the English subject in Norway. The aim is to see what role various modes and their interaction play in the examination and its preparatory material. Broadly speaking, multimodality "highlights that people draw on distinctly different sets of resources for making meaning" (Jewitt, Bezemer, \& O'Halloran, 2016, p. 158). Texts that create meaning from several semiotic resources, suchas speech, writing, pictures, colors, sound, and so on, are multimodal texts. Central here is the interplay between modes (Maagerø \& Tønnessen, 2010, p. 32). The Norwegian curriculum for the English subject does not use the term 'multimodal texts' per se. It does, however, apply an extended notion of text. When the extended notion of text was first introduced, it marked quite a revolution from the print-based notion of text:

A text may be spoken or written, prose or verse, dialogue or monologue. It may be anything from a single proverb to a whole play, from a momentary cry for help to an all-day discussion on a committee. A text is a unit of language in use. (Halliday \& Hasan, 1976, p. 1)

This view of text as being more than printed words was soon adopted into the subject curriculum for English, and is still applied: "Oral, written and digital texts, films, music and other cultural forms of expression can further inspire personal expressions and creativity" (Udir, 2013, p. 1). This article contributes to the research field of English education by using a social semiotic multimodal analysis to show what role multimodal literacy plays in summative assessment in the English subject in Norway.

\section{English in a Norwegian context}

English is ubiquitous in Norwegian society, especially in popular culture such as music, gaming (Brevik, 2016), film, and television (dubbing is unusual, except for child audiences (Dahl, 2014, pp. 28-29)). Norway has been in the top five on the English Proficiency Scale for Europe since 2011 (Education First, 2018). In school, English is a core subject, taught during all ten years of compulsory 
primary and lower secondary ${ }^{1}$ education. Ultimately, in 10th grade (15-16 yearold students), a selection of students is drawn to sit a final written examination. Students are to have attained both subject-content knowledge, connected to literature, culture, society and history in the English-speaking world, and mastery of form, in terms of linguistic and formal communication and recipient awareness (Udir, 2013, p. 3).

The English examinations start with an obligatory preparation day, in which all students gain access to preparation material. The teacher guides the students, who can work either alone or together to prepare for the individual written examination. All means of help are allowed while preparing, including using the Internet. Although the guidelines do not state it explicitly, the students may use a digital memory stick to save sources and items they find useful for the examination, such as images and texts. They bring this memory stick with them to the examination the next day, at which time the Internet will not be available to them. Being able to cite sources is part of the (digital) literacy skills being tested.

Norway may be of interest internationally, as the digitization of education and the written examination has come farther in Norway than in many other countries $^{2}$. The English written examination is administered nationally and therefore constitutes an important signal of what the Norwegian Directorate for Education and Training (Udir) expects from students' competence regarding the subject's curriculum. Norwegian curricula are outcome-based, and do not specify syllabus texts or specific topics. National examinations (as well as textbooks and traditions) can therefore be expected to influence classroom practices. Furthermore, the examination is digital and technically open to a rich multimodal practice. Since the curriculum applies an extended notion of text, it is relevant to look at how the examination deals with this phenomenon.

\section{Literature review}

Researchers across the world have shown an interest in how modes and multimodality affect the teaching and learning of English as a school subject. This research has been conducted, predominantly in contexts where English is the official language, with students who are learning English as their first or additional language (e.g. Beavis, 2013; Belcher, 2017; Bezemer \& Kress, 2009; Choi \& Yi, 2016; Guichon \& McLornan, 2008; Howell, 2018; Jewitt, 2006, 2011; Kress et al., 2005; Royce, 2013; Stein, 2000). The high proficiency level in Norway makes this research relevant to the present study.

Several researchers, such as Jewitt (2003), and Yi, King, and Safriani (2017), have pointed out the need for assessment tools that recognize multimodal literacy

\footnotetext{
${ }^{1}$ Though this article is written in American English I use the British term lower secondary school, as this is the term used in official Norwegian curriculum translations.

2 The European Commission's Digital Scoreboard of “Individuals with basic or above basic digital skills” shows Norway in second place, surpassed only by Luxembourg (2015, p. 19).
} 
in English education. A decade ago, Jewitt found that writing was the dominant mode in assessment in the UK: "While learning draws on a wide range of images and non-linguistic resources, mainstream methods of assessment used in schools persist in being almost entirely mono-modal” (2008, p. 52). In Sweden, Godhe (2014) similarly found that first-language multimodal texts tend to be assessed on the basis of written text. Unsworth (2014) has looked at national testing in an Australian context, finding that curricular goals for multimodal literacy are significantly less prominent than could be expected.

Multimodality in education has been researched in Norway from a societal perspective by Smidt, Tønnessen, and Aamotsbakken (2011), from a crosscurricular viewpoint by Løvland (2006, 2011), and from the perspective of outof-school literacy by Michelsen (2016). In Norwegian as a school subject, Kruse (2018) explored benefits of primary school multimodal text production. Burgess (2016) researched transduction from short story to film in lower secondary school, and found that the assessment of multimodal texts in first language teaching was difficult for teachers and that the end product, rather than the process, formed the basis for assessment. Other studies, such as that of Silseth and Gilje (2017), discuss how assessment practices can be developed to use both formative and summative assessment when working with multimodal texts in lower secondary schools. Assessment and multimodality thus emerge as a challenging and still developing matter for education.

Multimodality has received little attention in connection with English as a foreign or second language in Norway. Exceptions include Skulstad (2009, 2018), who has researched textbook tasks and calls for a new conception of communicative competence that includes multimodality. Furthermore, Ørevik (2012, 2019) has studied upper secondary English examinations with a focus on genre, including multimodality. Visual studies, by researchers such as Lund (2002, 2016) and Waallann Brown and Habegger-Conti (2017), have investigated textbooks for English, finding a tendency to use stereotypical images that potentially counteract the intercultural aims and tolerance proposed by the curriculum.

\section{Aims and research questions}

This article aims to provide new insight into the field of English education, by exploring the multimodal aspects of the final examinations, and asks the following research questions:

- Which modes are employed, and in which ways do they contribute individually, and in the multimodal ensemble, to the digital English examination?

- What signals do the texts and tasks give concerning what is considered relevant literacy within the English subject today? 
The next section gives an overview of the analytical framework. Theoretical framework

\section{Modes and multimodality}

Modes are "socially shaped, culturally available material resources" for communication (Bezemer \& Kress, 2016, p. 7). Modes have different affordances, that is the potential and limitations of what a mode can do. Music, for instance, can create mood in ways that words cannot (Tønnessen, 2012). A multimodal text can present meaning beyond the sum of its individual parts. Interplay between modes is often based on using the most apt mode to communicate or represent meaning, what is called functional specialization (Bezemer \& Kress, 2016, p. 24; Kress, 2003, p. 46). On a driver's license, for example, an image can immediately affirm the identity of the driver, whereas details concerning his or her qualifications are given in writing. In a multimodal text, one mode can be more prominent in conveying meaning, carrying the functional load (Bezemer \& Kress, 2016, p. 24), sometimes regardless of its specialization or aptness.

Defining a mode is easy in abstract terms, but in practice it is not simple. In an empirical study of multimodality in secondary school science in London, researchers noted that mode depends on context:

...we may regard visual image to be a mode, while a professional photographer will say that photography has rules and practices, elements and materiality quite distinct from that of painting, and that the two are distinct modes. (Kress, Jewitt, Ogborn, \& Tsatsarelis, 2014 [2001], p. 53)

The definition of mode is influenced by practice, and what is of use to distinguish as a mode. In the Discussion section, I will explore the question of which modes are recognized in the context of the English examination.

Multimodal analysis concerns paying attention to the choice and integration of modes, noticing what role each mode plays in the ensemble. All communication and all texts are multimodal (Baldry \& Thibault, 2006, p. 19), and there is no such thing as monomodality to serve as an antonym for multimodality, except as a theoretical antithesis. This highlights the problematic aspect of the research findings mentioned in the literature review, in which assessment tends to focus on written text. Multimodal theory regards language as one of many ways of making meaning (Bezemer \& Kress, 2016; Jewitt, 2006, Norris, 2004). A multimodal approach to communication sees all modes as having equal semiotic standing or potential to contribute to meaning (Bezemer \& Kress, 2016; Jewitt, 2014, p. 15) and, thus, asks for a readjustment of the Vygotskyan notion of language as human beings' most important psychological and cultural tool (Vygotsky, 1986). In a subject such as English, however, language is still center stage, and multimodality may be more about recognizing modes interacting with 
language, and not necessarily supplanting it. The recognition that language is always combined with other modes leads to the issue of multimodality's relation to literacy.

\section{Literacy, multimodality, and digital texts}

Multimodality is not a new phenomenon, but with digital communication it becomes easier to combine modes, and this in turn changes the way we write, read, and learn. Several studies have suggested the need for a view of literacy that includes multimodality (e.g. Jewitt, 2003; Tan \& Guo, 2009; Walsh, 2008, p. 101). Computers are now a natural part of school, and changing the medium "from page to screen" (Snyder, 1998), makes a wider variety of modes available (Danielsson \& Selander, 2016; Kvåle, 2015; Mills, 2010). The preparation material of the English examination used to be published as a paper booklet but is now a website, a medium that offers modes and affordances that differ from those of paper (Kress, 2003). Likewise, the students produce their response on computers and, in the Analysis section, I will look at the questions in relation to the preparation material and discuss how affordances of digital texts are included in the tasks set in the examination.

Sewell and Denton (2011) suggest that multimodal literacy "recognizes that for many children, knowledge construction has shifted away from the static, printed text to dynamic texts supported by sound and pictures" (p. 61). Multimodal literacy, according to Skulstad (2018, p. 263), "is the ability to interpret and use multimodal semiotic resources and multimodal genres in a successful way." Furthermore, van Leeuwen points out that

Such a form of literacy must be based on a knowledge of what can be done with different semiotic modes and how and of the ways in which they can be integrated into multimodal texts; however, it also, and equally importantly requires an understanding of communicative contexts and an ability to respond creatively to the unique demands of specific situations. (2017, p. 5)

The situation of the examination is the focus in the present paper. Bringing in the context also brings in the issue of meaning making and social semiotics: "Recognizing the agency of the sign maker and their (implicit or explicit) intentionality is central to a social semiotic approach" (Jewitt, Bezemer, \& O'Halloran, 2016, p. 68). Although it is challenging locate the intentionality behind a text, social semiotics regards signs and texts as semiotic indications from which meaning can be read.

\section{Visual modes and interplay with written text}

In school English, visual modes constitute an important part of the textual practices, reflected in the fact that images have been included in final English examinations in Norway since the 1950s (Gundem, 1989, pp. 118-131). In my analytical approach, I draw on Kress's and van Leeuwen's works on 
multimodality and, particularly, on image-text interaction and multimodal cohesion (Kress, 2003; Kress \& van Leeuwen, 2006; van Leeuwen, 2005). Multimodal analysis in this article will begin with multimodal ensembles, asking how each mode may contribute to the meaning made (Bezemer \& Kress, 2016, p. 24).

Naturally, in a written test, writing provides the majority of information and thus carries the functional load, but how does writing interact with other modes? Analysis in this article will use the fine-grained framework developed by van Leeuwen (2005). He has outlined five categories of information linking between word and image. The first two are ways in which one mode elaborates another: specification (in either the form of anchoring or the form of illustration) and explanation (elaborates the meaning potential that text can give an interpretation of what an image means and vice versa). The next three are ways in which one mode extends the meaning potential of another: similarity, contrast, and finally complement (one mode gives information that the other does not) (van Leeuwen, 2005, p. 230).

\begin{tabular}{|l|l|l|}
\hline Image-text relations \\
\hline Elaboration & Specification & The image makes the text more specific (illustration) \\
& Explanation & The text makes the image more specific (anchorage) \\
\hline Extension & Similarity & The content of the text is similar to that of the image \\
& Contrast & The content of the text contrasts with that of the image \\
& Complement & $\begin{array}{l}\text { The content of the image adds further information to } \\
\text { that of the text, and vice versa ('relay') }\end{array}$ \\
\hline
\end{tabular}

Figure 1: Facsimile of van Leeuwen's model (Fig. 11.4 Overview of visual-verbal linking, 2005, p. 230).

These ways of looking at relations between image and verbal text are useful for establishing multimodal interplay, together with other aspects such as composition of the multimodal ensemble.

Reading paths are more open in multimodal than in print-dominated texts (Bezemer \& Kress, 2016, p. 43). Orchestration on a page can be visually arranged, for instance by grouping or clustering: "Clusters of items and objects on, for example, a web page are small-scale arrangements of items which are nested within larger wholes” (Baldry \& Thibault, 2006, p. 31). Other ways of orchestrating a page, and possible reading paths, are framing, font and layout. In addition to information linking, the analysis makes use of two other ways of creating cohesion that van Leeuwen calls "rhythm" and "composition". Rhythm pertains to issues of composition in both time and space (layout) and the regularity of alternation between modes. Rhythm can create cohesion or disruption, the latter not a feature that I anticipate finding in the examinations. Composition refers to 
spatial layout, such as borders, clusters, central or marginal placement of modes, which can structure the "information value" of elements in a text (van Leeuwen, 2005, pp. 179-218).

\section{Methods}

\section{Sample and rationale}

National examinations from the years 2014 to 2018, the five latest to date, make up the data material. The selection of these five $10^{\text {th }}$-grade examinations is based on the revised English subject curriculum that came into effect in 2013. Examinations prior to 2013 tested a different curriculum outcome, and comprised a greater number of texts. Each examination consists of online preparation material and the actual examination. In addition, there are guidelines, which are drawn into the discussion in this article. Findings presented in Section 4 are illustrated with representative examples and, in some cases by illustrations of the atypical, which by their contrast make it easier to see the conventional.

Choosing examinations as material for analysis is based on the understanding that tests and examinations are likely to have an impact on teaching, learning and assessment: often referred to as the washback effect (Alderson \& Wall, 1993; Simensen, 2007). This term has sometimes been used negatively to describe the way some schools "teach to the test". Ytreberg (1993, pp. 128-129) gives an example of how, despite curricular requirements, oral skills in English were given less priority during the final year of lower secondary school in Norway, until oral final examinations were established in 1988. Alderson and Wall theorize that, the more important and consequential an examination, the more likely it is to have a washback effect (1993, p. 120). This article focuses on the written final examination in English, which is highly consequential: together with the oral examination, it has a direct impact on the grade point average and, thereby, admission to upper secondary school.

The examination is designed to summatively assess curricular content knowledge and literacy skills, and it would hardly be fair to negatively characterize teaching according to the curriculum as teaching to the test. A positive washback effect could even be envisaged, in that Udir has an opportunity to operationalize its understanding of the curriculum and, consequently, to influence school practice, by what and how it chooses to test. Overall, this makes an analysis of the five most recent examinations both valid and relevant for studying the role of multimodality.

\section{Analytical methods}

The analysis is divided into two main parts, looking at the preparation material and the examination tasks, respectively. Step one in exploring the preparation material for all five years starts by identifying the number of texts and modes 
used. As pointed out in the introductory paragraph of the material for the 2014 examination: "The preparation material includes factual and fictional texts as well as pictures that present aspects of Civil and Human Rights”. Establishing themes is of interest for the next analytical step. By gaining an overview, it becomes possible to discern patterns within each year's examination and across years.

Subsequently, step two of the analysis goes into detail, and considers the functions that writing and other modes have in the preparation material. By making a close reading, hermeneutically spiraling between part and whole, and focusing on the interplay between modes, I will use the analytical categories of multimodal cohesion outlined by van Leeuwen (2005). The present analysis takes into account rhythm, composition, and information linking. I will give illustrative examples of the interaction of modes that may take place, when students read and prepare.

In the third analytical step, the examination questions are investigated. I start by briefly considering the tasks as multimodal texts in themselves, using the same framework of multimodal analysis as above. Next, the analysis turns attention to the examination tasks the students are given. Does responding to the tasks depend on multimodal literacy, on reading the information found in modes other than (or combined with) written text? Furthermore, do the questions ask students to produce their content in modes other than written text? This leads me to the fourth step, where I investigate what the guidelines for the examinations state about modes. Which modes are the students invited to use in their creation of texts?

\section{Ethical considerations}

Researching examinations requires some ethical considerations. While examples are desirable for research transparency and for a clear line of reasoning, original copyright holders, examination copyright, and the assessment genre itself all pose restrictions. In my writing, I aim not to spoil the use of previous tests for classroom use as mock examinations, nor do I wish to reveal information that would give readers undue advantages in future examinations. I therefore paraphrase, and endeavor not to disclose details beyond those that are necessary for my discussion. Permission to use the original artworks shown in this paper has been obtained from the copyright holders.

\section{Analysis and findings}

Commencing descriptively with the preparation material first, and the tasks last, this section will proceed to show analysis and findings, including examples. Structurally, all five years' examinations are quite similar. 


\section{Preparation material}

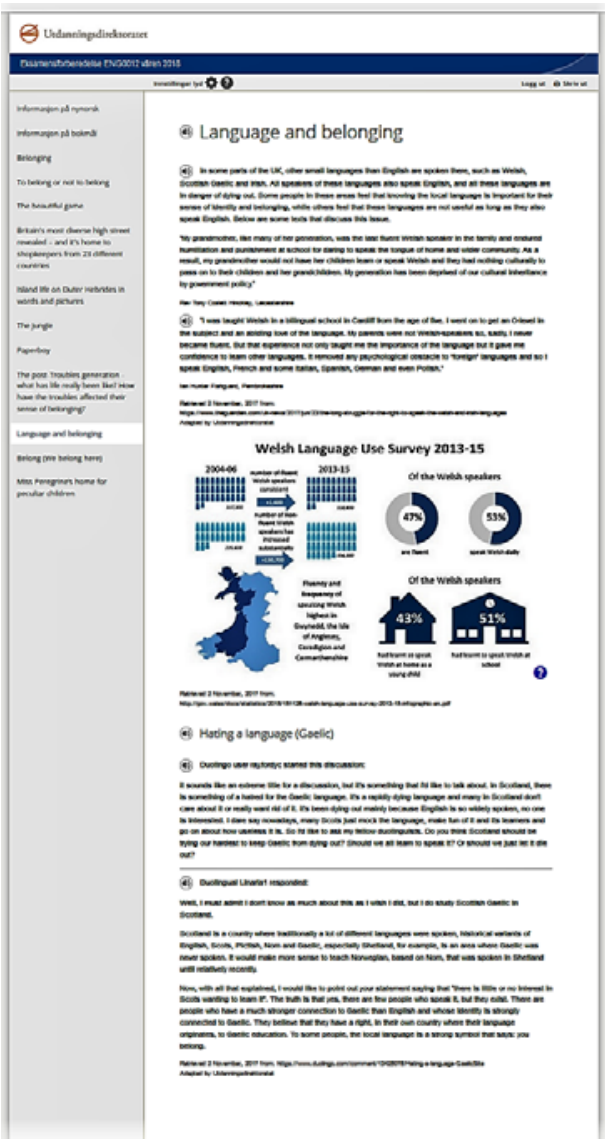

Figure 2: Screenshot from the $201810^{\text {th }}$ grade preparation material, showing the layout of the full scroll-down page

\section{Layout and modes}

All the examinations for 2014-2018 have preparation material organized as regular websites with a fixed left-hand navigation menu of hyperlinks (see Figure 2). The layout is sober, with font type and size used to distinguish headings from content, creating a steady rhythm. Color is used for framing, with banners in blue, and logo in orange, as stable compositional features across the years. Giving the students time to prepare is intended to stimulate the use of learning strategies and cooperation skills, as outlined in the curriculum (Lunde \& Skeiseid, 2013, p. 40 ), and constitutes positive washback.

The number of texts (not counting guidelines) remained unchanged at eight, until the preparation material for the two latest examinations arrived with ten and eleven texts, albeit with a relatively similar total word count. Texts typically range from literature passages, newspaper pieces, web pages and quotations, to lyrics and speeches. Table 1 provides an overview of the distribution of written text and images ('infographics' will be explained below). 
Table 1: Overview of the distribution of written text and image in the $10^{\text {th }}$ - grade English examination preparation material, years 2014-2018.

\begin{tabular}{|c|c|c|c|c|c|}
\hline Year & 2014 & 2015 & 2016 & 2017 & 2018 \\
\hline Title & $\begin{array}{l}\text { If I were you } \\
\text { and you were } \\
\text { me: } \\
\text { Stereotypes } \\
\text { and prejudices }\end{array}$ & Challenges & $\begin{array}{l}\text { Around the } \\
\text { world: } \\
\text { Exploring } \\
\text { some } \\
\text { English- } \\
\text { speaking } \\
\text { countries }\end{array}$ & $\begin{array}{l}\text { How we } \\
\text { connect } \\
\text { online and } \\
\text { offline }\end{array}$ & Belonging \\
\hline Number of texts & 8 & 8 & 8 & 10 & 11 \\
\hline $\begin{array}{l}\text { Texts without } \\
\text { images }\end{array}$ & 5 & 2 & 4 & 2 & 4 \\
\hline $\begin{array}{l}\text { Texts with } \\
\text { images }\end{array}$ & 3 & 6 & 4 & 8 & 7 \\
\hline Infographics & 0 & 1 & 0 & 3 & 1 \\
\hline $\begin{array}{l}\text { Total number of } \\
\text { images } \\
\text { (including } \\
\text { infographics) }\end{array}$ & 7 & 10 & 6 & 9 & 11 \\
\hline
\end{tabular}

The number of texts with and without images varies from one year to another. What is a stable pattern, not discernible in Table 1, is the fact that fiction texts are those that generally come without images (see the Discussion section). The absence of illustrations, so consistent in literary texts, makes the exceptions conspicuous. In the 2018 preparation material, there is one text with extracts from a novel, accompanied by two photos from Northern Ireland, where the novel is set. Similarly, in the 2017 preparation material, appended infographics appear at the bottom of the fictional texts. Headings, however, separate the infographics from the fiction excerpts, forming separate clusters. Consequently, the images in the composition seem less strongly related to the narrative, despite belonging to the same hyperlink or page. 


\section{Written mode in ensembles}

Written text carries the functional load in the preparation material in general, even when several images are present. Figure 3 gives an example of a text assembled and constructed for the examination. Three proverbs from around the world are quoted. Thematically, text and image are related in all three clusters; the images relate to and illustrate parts of each written text (van Leeuwen, 2005, pp. 229230). Written text carries the functional load; the written parts would even make sense and create coherence between them without the images. To some extent, the images are superfluous, though not disconnected from the whole. One possible

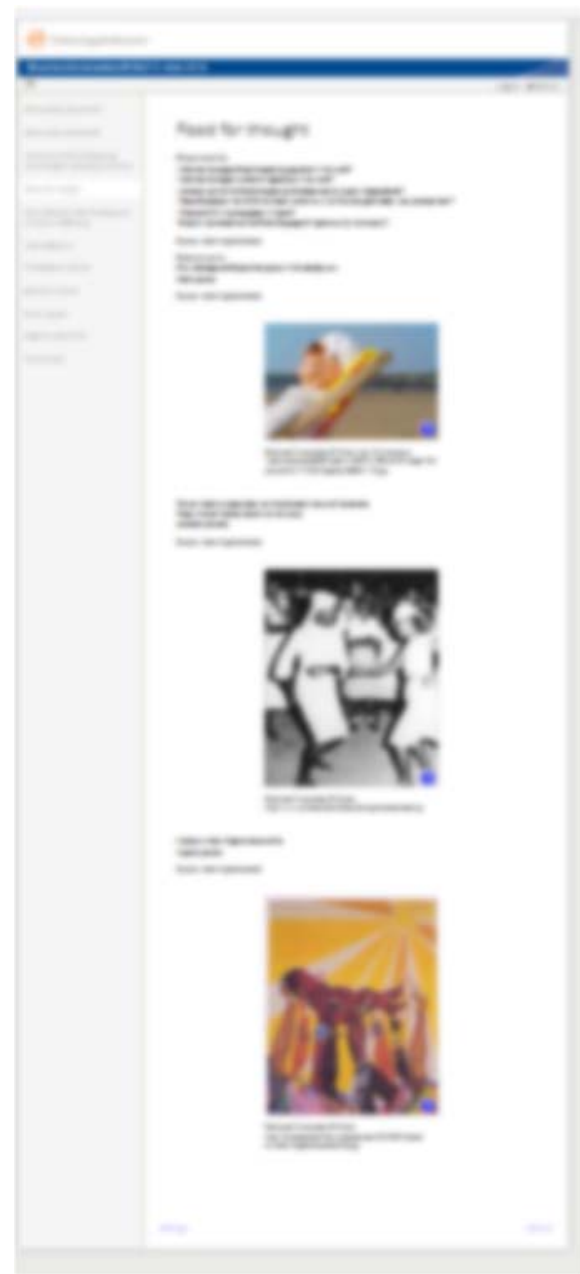

Figure 3: Screenshot from the $201610^{\text {th }}$ grade preparation material, showing the full scrolldown text, and text-image distribution, rhythm and overall composition (blurred to prevent copyright infringement). function of the images, important for language learning, is to give students space and a concrete starting point for thinking more about the full meaning of each proverb. In this respect, the images not only illustrate, but also work to extend by similarity, the meaning of the words. For this valuable function to apply, the students must pay attention to, or take an interest (Bezemer \& Kress, 2016) in, the images. None of the written texts mention the images, or refer to them. There is no metalanguage in the form of 'as seen in the picture' at all. Positioning is used to create potential cohesion, not metalanguage.

Captions constitute a second kind of written text in each cluster and in the ensemble as a whole. Both here and elsewhere (and throughout the other years' preparation material), captions are written in a different font and state the digital source of each image. One quite pragmatic interpretation may be to see the captions as models for the students to follow in how to cite sources. Another pragmatic function is that students can use the digital sources to search online for further information and contextual clues. On the whole, this sample shows that students need to take different fonts, layout and images into account when reading the clusters and the ensembles. 


\section{Images in ensembes}

All the images used in the investigated preparation material reflect the themes in the written texts. In other words, the images serve a purpose and play a communicational role and are neither random nor purely for decoration. Decoration may of course be an aspect of any image's function, but it is significant that every image does take part in the thematic interplay of each year's examination. In language learning, it makes sense that images repeat or emphasize text and thus act as scaffolding for understanding language. Nevertheless, the aesthetic pleasure in images and in contemplating the multiple possible meanings of image (as, correspondingly, of text) also has some place in the preparation material.

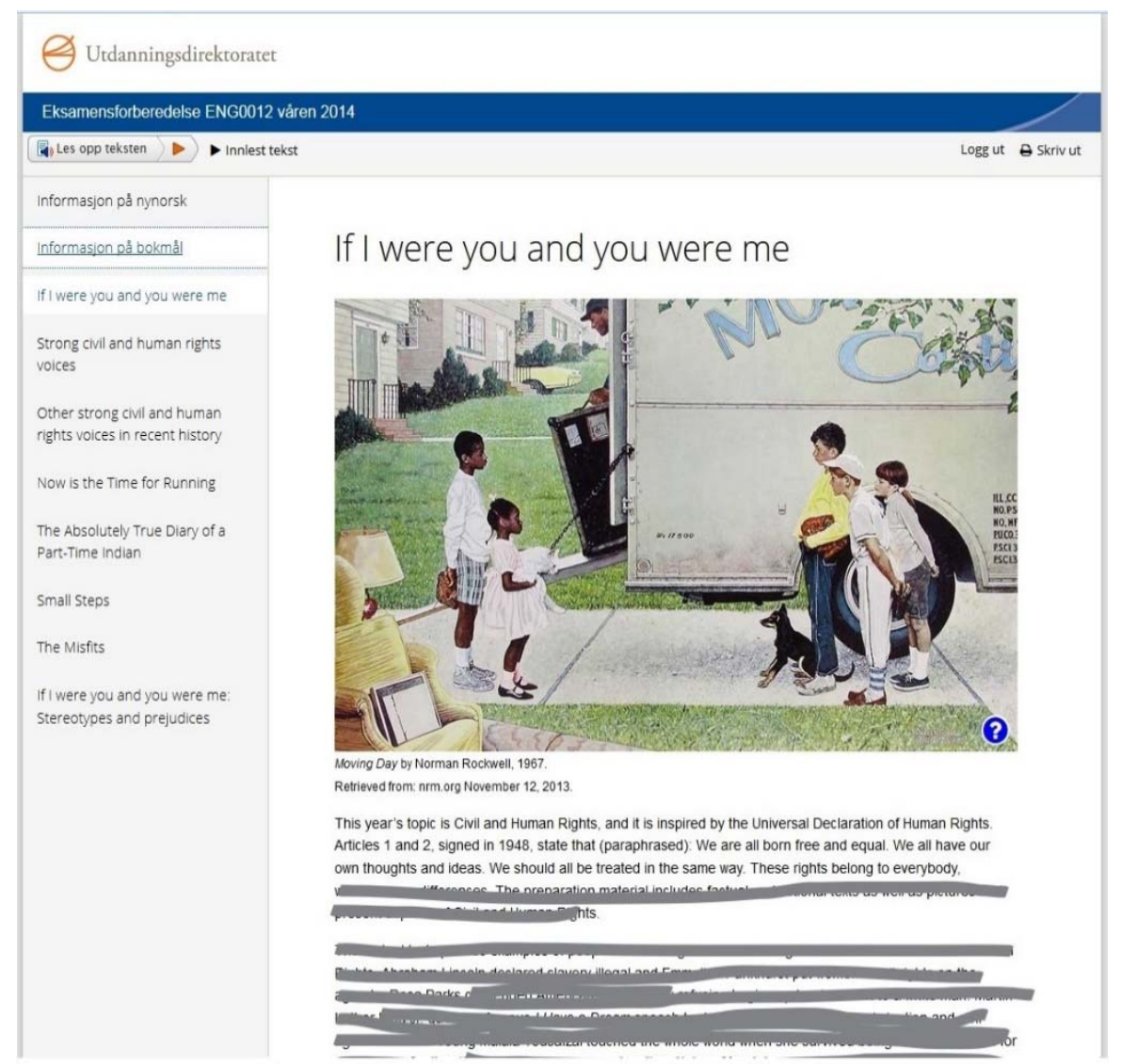

Figure 4: The first content page of the $201410^{\text {th }}$ grade preparation material, featuring "New Kids in the Neighborhood” by Norman Rockwell. Reproduced in this article with kind permission of the right holders, the Norman Rockwell Family Agency.

Above is a screenshot of the first content page in the preparation material for 2014, of which I will proceed to perform a close analysis. As with all five preparation websites, the first text serves to introduce the general topic; as such, 
this page is representative. When opening this page, students' eyes may be drawn first to the image, and they may start their reading path based on the central position of the image. Another natural starting point is in the upper left corner, as most Western cultures use the left-to-right directionality (Kress \& van Leeuwen, 2006, p. 204). The logo and name "Utdanningsdirektoratet" are found here, but, though this states the name of the producer of the test and gives the document an added feeling of formality, the logo may be passed over as less important information for students in the examination situation. The image shows two black children on the left and three white children on the right, all looking directly at each other, leaving the viewer as an outsider looking in on the scene. The relationship between the viewer and the image is that of 'offer' (Kress \& van Leeuwen, 2006, p. 119), in which the image contains items of information or contemplation. Images allow a freer reading path than the linearity of text, and "[i]n image, imagination focuses on creating the order of the arrangement of elements which are already filled with meaning” (Kress, 2003, p. 4). Some elements of the scene constitute contextual clues, such as the clothes the children wear and the row of identical suburban houses. Nevertheless, what the image represents in itself or offers as part of the preparation material as a whole may not be evident.

Next in their reading path, students may look at the printed headline, which gives only a vague clue to the image's context: "If I were you and you were me". The headline and the posture of the children in the image may together give an understanding of the theme as curiosity towards one another and what it would be like to be in the others' shoes. The printed caption below the image gives the title, artist, year and source of the image: “Moving Day' by Norman Rockwell, 1967. Retrieved from: nrm.org November 12, 2013"3. All these pieces of information can help the students make meaning of the image in the given context. The printed body of text following beneath specifies the intended link for the students and anchors the image, when it straightforwardly states that "This year's topic is Civil and Human Rights, and it is inspired by the Universal Declaration of Human Rights....". A student may of course choose a different reading path from the one sketched out here. However, shifting between the written words and the image, going back and forth between modes, one influencing the interpretation of the other, it becomes clear that skin color in the painting may be another factor to be considered in the image. The image is a depiction of integration in Chicago in the 1960s.

There are four short paragraphs of printed text below the image. These explain the context and thus simultaneously open up and narrow down the meaning potential of the image, just as the image both extends and possibly elaborates the theme of the text. The paragraphs and the image as a whole point forward to what will follow in the rest of the texts in the preparation material.

\footnotetext{
${ }^{3}$ Norman Rockwell paintings are even used in the preparation material for examinations for 2000, 2001, 2003, and 2006 (Reisjø, 2006, p. 73).
} 
My analysis shows that most of the texts dealing with cultural, societal or historical topics are illustrated in all five years of examination preparation material. As a rule, the images in the examinations are less open than the above example and tend to elaborate rather than extend the meaning potential. There is one single occurrence of an image (Figure 5) extending the meaning of the printed text to the extent that it can be characterized as bringing in new information.

The image in Figure 5 is part of a page containing four quotations about belonging (preparation

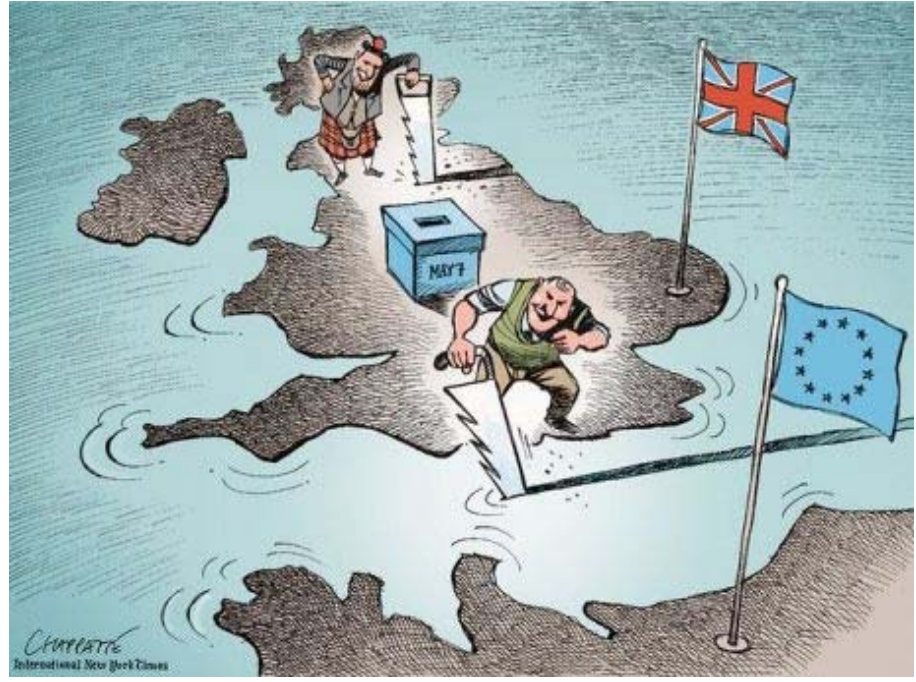

Figure 5: "Brexit" by Patrick Chappatte, from New York Times International. Reproduced in this article with kind permission from the artist. (c) Chappatte, The New York Times www.chappatte.com material 2018). None of the quotations mentions Brexit or the Scottish independence referendum, nor are these topics mentioned in the rest of the preparation material; thus, the image and its caption (which contains the words "brexit-humourcartoons" in the source's URL) introduce a new aspect and challenge the rhythm.

Image rarely carries the functional load of meaning making in the English examination. One example to the contrary is in the 2017 test, in which there is a page bearing the headline, "Cartoons", in the standard font. Two satirical newspaper cartoons comprise the contents, with sources given beneath. The juxtaposition of the two cartoons is a design assembled by the test developers. The theme in both cartoons is how social media change interaction and friendship. Both cartoons use image in combination with printed verbal mode, with the information linking being that of contrast in one and complement in the other. This expansion is necessary, as neither cartoon would be fun without the interplay of modes. The caption is simply the digital source, and, as mentioned, this can function as anchorage if the reader pays attention to it.

Images can differ greatly; for the purpose of this analysis and as indicated by Kress in the earlier quotation, I have not found the need to distinguish between photo and painting or between cartoon and drawing. Nevertheless, I do wish to point out another kind of visual. Statistical information, shown as charts, pie diagrams, or graphs, is called infographics. 


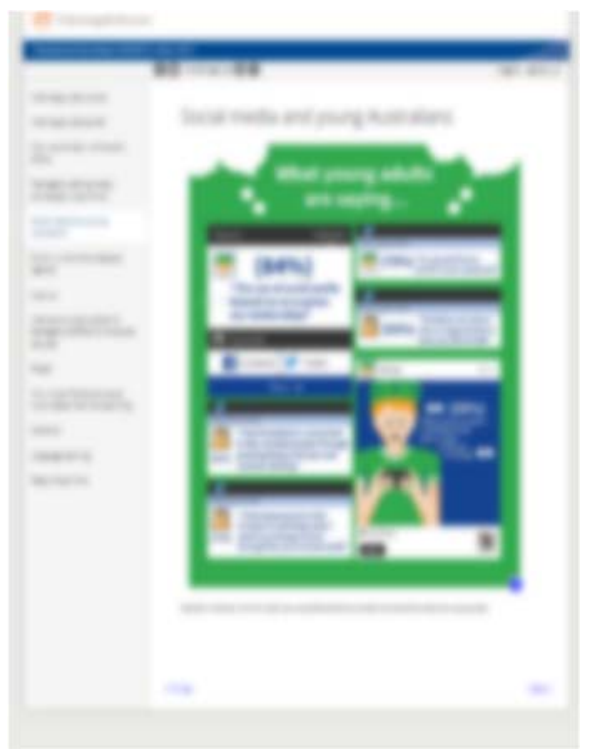

Figure 6: Infographics from the $201710^{\text {th }}$ grade preparation material (blurred to prevent copyright infringement).

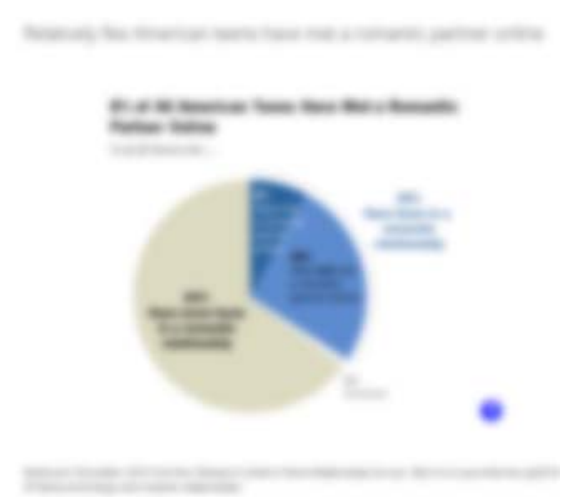

Figure 7: Screenshot of part of a text in 2017 preparation material, showing pie chart and its colors (blurred to prevent copyright infringement).

\section{Infographics}

Infographics are clusters with high 'modal density' (Norris, 2014), where visual resources, such as shape, color and symbols, interact with writing, and the relationship is complementary. Based on conventions, they convey specific information. Infographics feature prominently in the 2017 examination. The most striking occurrence is shown in Figure 6. This large and unusual infographic collage of different social media messages, framed by a dark green background, forms a visual unit (Baldry \& Thibault, 2006, p. 86). A girl and a boy feature as the communicators, and the infographics thus "use the pedagogical opportunity of illustrating and making contents concrete by use of 'individuals' - as is often done in journalistic infographics" (Engebretsen, 2013, p. 123). In fact, these are statistical facts about social media use, aptly presented as if they were Instagram posts and Twitter tweets, albeit in a cartoonish rather than a realistic style. Otherwise dry facts come to life in an appealing and compressed way.

Making meaning from graphic and statistical material is a part of numeracy skills in the English curriculum. Infographics appear in the 2015, 2017 and 2018 preparation materials. The 2017 examination features two pieces of infographics: a pie chart (Figure 7) and a bar graph chart. I have counted infographics as images in Table 1 , for they are dominated by shape and color in different nuances and must be read visually and spatially, combined with text that gives them meaning. The two instances of infographics in 2017 stem from the same source and thus have the same colors and style, but are placed at the end of two different text pages. Textually, this provides uniformity across the preparation material. The uniformity and the appendage of 
the infographics in turn give a somewhat instrumental feel, as if placed there to provide students with a chance to demonstrate skills in reading statistical figures.

Ideationally, the infographics (Figure 7) offer information about young people's use of the Internet, and they contribute to the overall theme of the test, with their compact and rich contents presented in distilled form. The colors are deceptively similar to the colors of the Udir blue and grey profile headlines, and, though this seems to be pure coincidence, the interpersonal effect is that of a factual and even authoritative relation to the reader. This might make it less natural for students to question the reliability of the graphs.

To summarize, the preparation material for all years' examinations comprises carefully composed multimodal texts. Images, including infographics, and layout and color contribute to meaning making in well-orchestrated smaller and larger clusters, all connected to the overall theme of the preparation material as a whole.

\section{Examination questions}

This section considers the set examination task: first, the examination document as a multimodal text and, secondly, the role of multimodality expressed in the questions. Tasks are handed out as a paper booklet, but students use computers to

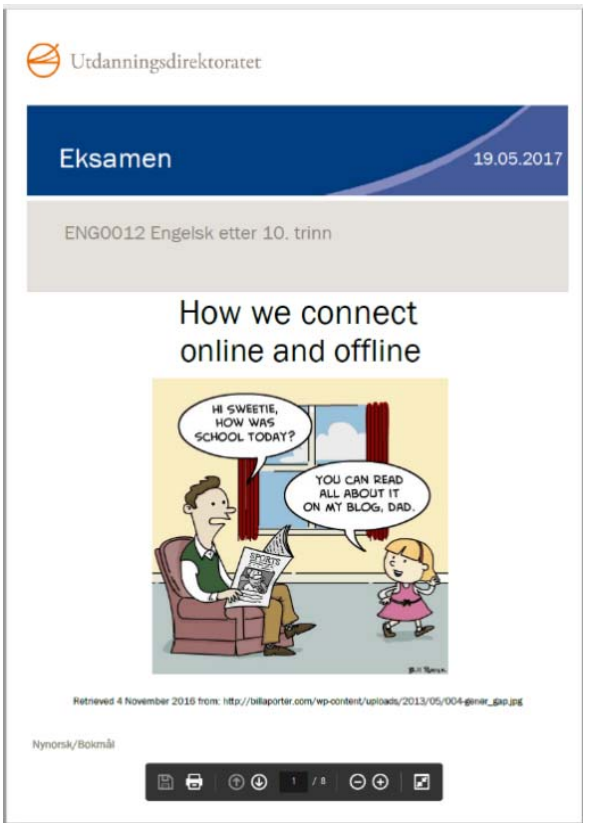

Figure 8: Front page of the 2017 $10^{\text {th }}$ - grade examination, featuring "Generation Gap" by Bill Porter (C) 2007; image reproduced with permission. produce their responses. The front page (see Figure 8) is highly visual, with the Udir logo, a recurring blue/grey framed formal heading that comes with all publications from Udir; the specific topic heading; and a large image that is a facsimile of the first image used in the online preparation material. Visual coherence across years and across examination parts is thus created, giving a sense of authority and stability. For students sitting the test, the image on the front page of the examination is one they recognize from the preparation material. Textually, it binds the examination parts together. Interpersonally, it can create a sense of familiarity that can ease examination anxiety, and, ideationally, it reminds the students of the theme of the test.

The rest of the task booklet is dominated by printed text, using layout such as headlines and bullet points to visually contribute to meaning making.

Regarding the actual tasks, all five examinations analyzed here are structured in 
answered. These two are connected to reading. Task 1a relates to the preparation material, in which several texts are rich multimodal texts, whereas Task $1 \mathrm{~b}$ asks the student to read a short new appended text and write a comment, including personal opinions. The appended text comes without image, rendering multimodal literacy virtually unnecessary, except for the visual qualities of the writing.

Part 2 is closely connected with the preparation material. Students select one of four different tasks and compose a long answer. From a multimodal perspective, it is significant that the first three years examined here all have one task that incorporates image. For example, Task 3d in 2014, states:

Look at the Norman Rockwell painting on the title page. The title of the painting is "Moving Day", and it is from 1967. Create a text inspired by the painting. Include the following:

- Describe the painting and its setting

- Choose one of the children in the painting and describe what he or she is thinking about

- Discuss what the painting reveals about race issues in the USA

In the above task, image works as an inspiration and prompt for writing; it also generates the connecting of culture and history with the visual expression. It is noteworthy that the verb write is not found in the tasks. Most of the tasks, in all years examined, use the verb create, which could indicate an openness to the creation of multimodal texts. In the 2015 examination, image is less prominent but still an option as a prompt in a very open-ended task: "Create a text inspired by one or more texts or pictures in the preparation material..." (Task 2c). Then, in 2016, Task 2d includes another open task: “...Using one or more proverbs, texts or pictures from [the preparation] material as your starting point...” In spite of the 2017 and 2018 examinations having the largest number of texts with images, no tasks explicitly request that attention be paid to either an image or the interplay between the image and the textual contents.

\section{Discussion}

\section{Images can scaffold meaning making during reading}

This article began by asking which modes are employed in the English examination, and what kind of semiotic work is carried out by individual modes and the multimodal ensemble. Unsurprisingly, the written mode is dominant and carries the functional load in the preparation material. Images are a frequent mode, however, and their function in the examination is mainly to scaffold meaning making and, in some cases, to expand the meaning potential of the written words. The preparation day preceding the examination is intended to encourage reading strategy use as well as the use of learning strategies (Lunde \& Skeiseid, 2013). 
One such strategy can be to attend to the interplay between image and text in the preparation material. Norwegian learners of foreign languages tend to use a bottom-up approach when reading (Ibsen \& Wiland, 2000, p. 189). This means they put too much emphasis on detailed decoding and single words and sentences; in short, they cannot see the wood for the trees. Visual mode has the advantage of being quick to 'read' (Kress \& van Leeuwen, 2006), and, when used to carry meaning and function for information linking (as opposed to decoration), image can stimulate a top-down approach. This is true for any text, but it seems especially important for a foreign or second language. Clearly, the designers of the preparation material use pictures and infographics to scaffold meaning making. Images are part of the relevant literacy that can enable students to gain a sense of the overall theme without full verbal comprehension and use a top-down approach to understand details and make inferences about unknown vocabulary.

\section{Literature without visuals}

Those texts completely without image in the preparation material are predominantly excerpts from novels or song lyrics and poems. This reflects the high English literacy level expected from 10th grade students. Scaffolding for the fictional texts comes in the form of written introductions. Visually, frames separate the introductions from the literary excerpts, and font type and font size signpost the sources. Literary texts demand reading skills beyond functional literacy skills, what Nikolajeva (2014, p. 1) calls 'deep reading': “reading as an intellectual and aesthetic activity”. Bland (2015) points out how images and pictures, as scaffolding and shortcuts to deep reading, are useful for students of English. Yet, as shown in the previous section, images are generally not offered in literary texts. Factual texts, on the other hand, tend to be illustrated. 'Culture' may be a keyword in understanding this difference, as image can afford condensed and precise renditions of cultural contexts in factual texts. The combination may serve to make history more real. Maagerø and Tønnessen (2014, p. 227) have pointed out how factual texts in language textbooks tend to be illustrated with images that elaborate the meaning potential of the text, whereas fictional texts tend to be extended by visuals. Perhaps fiction, in the context of examination, is presented in a design with lower modal density to avoid complicating a demanding text by introducing more meaning potential through image. If so, images are regarded as extending and not elaborating the writing.

\section{Digital media}

Although digital media are by no means a prerequisite for making multimodal texts, they do offer opportunities for producing more complex texts, thereby affecting communication. The digital preparation material has a static left-hand menu of hyperlinked text titles, which means that the reader can gain an overview (Knox, 2007, p. 43) and choose his or her reading path; in the past, a paper booklet encouraged turning the pages in order. 
Digital format affords the mode of sound. Students who wish to hear the text read aloud can click to listen. While sound is foremost a means of support for visually impaired students, this possible combination of modes directly influences the meaning-making process. For instance, if students decide to listen without simultaneously reading, their eyes are free to scrutinize image, in much the same way that children listening to an adult reading a picture book are able to pay more attention to the image and the multimodal ensemble than the adult, occupied with reading for the children (Nikolajeva \& Scott, 2006). The sound option in the preparation material can be paused, slowed down, and replayed. Sound thus scaffolds the students' overall meaning making. Other potential modes, such as music, are not made use of, nor is the possibility of embedded video.

Perhaps digital infrastructure, such as Internet speed and software, imposes restrictions on modes like music and film. A possible circumvention of video use is found in the 2017 and 2018 examinations. The preparation materials reproduce in writing poetry performed on YouTube. It is likely that many students will copy the URL address given as the source and access the original video format. The transduction from recitation to writing (in which the poem is shortened with ellipses showing between stanzas) renders the text easily included in the preparation material's homogenized format. Moreover, the 2017 examination designers have added an illustration that connects with the last line and overall theme of the poem. The extended notion of text is perceptible in the preparation material; it is a multimodal text and images and ensembles must be "read".

\section{Modes for production}

So far, this article has demonstrated that the examination invites, and even requires, multimodal reading skills. This section discusses the literacy requirements of the tasks given. The analysis showed that the meaning potential of images is mainly reduced to inspiration. The examination in this sense does not apply an extended notion of text but interprets the curriculum literally: “...can further inspire ... creativity” (Udir, 2013, p. 1). Based on the long practice of using image as prompt, it is unexpected that the two most recent examinations do not include a task based on visuals. Furthermore, this lack contrasts with the high number of visuals in the preparation material for these same two years. Students can certainly include visuals in their texts, but they need to think of this themselves: the task does not suggest it. Correspondingly, an examiner may have trouble "rewarding" image use.

Students sitting the examination are requested to show awareness of the communicational situation. From a multimodal viewpoint, the examination guidelines contain an odd tension between choice and recommendations, when it comes to the visual qualities of writing:

To be able to present subject matter, to use aesthetic tools and to shape texts, is a part of the competence requirements in the English subject. You will choose for yourself 
how to best show your awareness of the recipient and show the intention of your texts. This also applies to the choice of font and font size.

The standard for the body of your text is font size 12 and line space 1.5. (Arial, Calibri and Times New Roman have good legibility.) (Udir, examinations 2014, 2015, 2016, 2017 [my translation])

What is most striking in the above quotation is the ambivalence resulting from the creativity expected from the students, and the restriction that follows, especially as this reiterates a similar recommendation presented in the preparation material. Manifestly, the digital medium means that font and layout are modes that, despite their ubiquity, carry meaning and emerge as literacy skills tested in the English subject. Digital skills in the curriculum entail an awareness of what can be called multimodal ensembles, as expressed in the examination guidelines: "Effects, images, tables, headlines and bullet points are composed to underline and convey a message" (Examination guidelines, 2017). This shows that multimodal visual qualities of the English subject are important.

\section{Communicational situation and creativity}

Another problematic point concerns the communicational situation (Bjørkvold, 2015; Knain, 2008; Troelsen, 2018). The ability to use language and texts for active participation is what Hasan (2001, p. 60) calls “action literacy”. At first glance, students are asked to show action literacy. Tasks use verbs such as 'explain' and 'create a text', and in some cases ask for personal opinions, as such the purpose of the text is expressed. Audience and the communicative context, however, are not mentioned. Consequently, students have only the vague figure of an external examiner to write for. In this sense, the examination tasks fail to invite students to demonstrate the ability to choose modes for successful communication. As Hasan points out, students in this situation may feel under pressure to meet expectations (Hasan, 2001, p. 61). Creativity in the use of font, composition, and rhythm in layout, and potentially adding images is not stimulated. It is likely that students will stick with the recommended fonts with "good legibility"; as a result, formal requirements such as font and layout are not truly an issue for assessment, unless students fall short of using the standards. Should students wish to produce a multimodal text similar to those found in the preparation material, they risk wasting their efforts. None of the rubrics in the official assessment form includes communication in modes other than words.

As the observant reader may have anticipated, the most recent examination from 2018 is different when it comes to recommendations about fonts. It has the same information, verbatim, as previous examinations, about being able "to present subject matter", but the lines recommending fonts have been removed. This gives more room for students' actual creativity and action literacy, which is even further emphasized by the pre-examination report issued on 30 May 2018 by Udir: "We reiterate that the examination guidelines say that students can interpret tasks in untraditional and unexpected ways, and the external examiner must be 
open to creative and unexpected solutions. ...” [my translation]. When it comes to recipient awareness, however, the overall question remains an unresolved one.

\section{Implications, limitations, and future research}

This article offers new perspectives on multimodality in English education, by showing that there is an imbalance between multimodal input and writingdominated tasks in the $10^{\text {th }}$-grade examinations. More generally, it contributes to discussions on literacy and the effects media have on reading, writing and learning in our digital world. Currently, a curriculum revision is in its finishing stages in Norway, and one of the pillars in the revisions, is to enable students to face technological change with creativity, and critical and participatory skills (Udir, 2018/2019). Perhaps this article can contribute to the ongoing discussions in Norway and abroad.

Possible limitations in this study of multimodality in English examinations include its concentration on the examination papers set and not on student responses. Further research into student writing, tasks and assessment, in relation to visual modes - in addition to and in interplay with verbal ones - could provide valuable added insight.

Multimodal analysis, as carried out in this article, may be repeated, even though there is an element of personal interpretation as with all semiotic analysis. More research could be conducted on future examinations, and in other contexts. It would also be of interest to compare the concept of multimodal literacy in language education in other countries.

\section{Conclusion}

This article has argued that the English written school-leaving examination constitutes a rich multimodal text. Written text, layout, and images are the main modes employed. It claims that the multimodal ensembles of the preparation material and the examinations are well-designed, cohesive wholes that communicate efficiently. Furthermore, it finds that students are mainly invited to read multimodal texts and not produce them. Considering the washback effect, it is likely teaching and learning in schools will focus on the same. Students are asked to demonstrate their literacy in written mode, in contrast to the rich multimodal text of the examination and despite the many affordances of modes available when producing text on computers. This indicates that what is considered relevant literacy in the English examination is the ability to read and learn from multimodal texts, rather than the ability to produce multimodal texts. 


\section{Acknowledgments}

I would like to thank the peer reviewers for their constructive feedback. I am grateful to Professor Kari Smith at NAFOL for her comments on an earlier draft of this paper. Thanks also go to Professor Aud Solbjørg Skulstad for her encouragement, to my colleague, Morten Bartnæs, for his feedback, to Elise Seip Tønnessen for her support, and to Annelise Brox Larsen for her eye for detail.

\section{About the author}

Ingrid K. Jakobsen is a lecturer in English literature and subject didactics for the teacher education programmes at UiT The Arctic University of Norway. Her research interests include multimodality in English, teaching in relationship to development of literacy.

Institutional Affiliation: Department of Education, UiT The Arctic University of Norway, 9037 Tromsø, Norway.

E-mail: ingrid.jakobsen@uit.no

\section{References}

Alderson, J. C., \& Wall, D. (1993). Does Washback Exist? Applied Linguistics, 14(2), 115129. doi: http://10.1093/applin/14.2.115

Baldry, A., \& Thibault, P. J. (2006). Multimodal Transcription and Text Analysis: A

Multimodal Toolkit and Coursebook with Associated on-line Course. Bristol: Equinox Publishing.

Beavis, C. (2013). Literary English and the Challenge of Multimodality. Changing English: Studies in Culture and Education, 20(3), 241-252. doi: http://doi.org/10.1080/1358684X.2013.816527

Belcher, D. D. (2017). On Becoming Facilitators of Multimodal Composing and Digital Design. Journal of Second Language Writing, 38, 80-85. doi: https://doi.org/10.1016/j.jslw.2017.10.004

Bezemer, J., \& Kress, G. (2009). Visualizing English: A Social Semiotic History of a School Subject. Visual Communication, 8(3), 247-262. doi: https://10.1177/1470357209106467

Bezemer, J., \& Kress, G. (2016). Multimodality, Learning and Communication: A Social Semiotic Frame. Oxon: Routledge.

Bjørkvold, T. (2015). Fra avskrift til populærvitenskapelig artikkel - mottakerbevissthet som didaktisk grep. Acta Didactica Norge, 9(1), 1-23. doi: http://dx.doi.org/10.5617/adno.2434

Bland, J. (2015). Pictures, Images and Deep Reading. Children's Literature in English Language Education, 3(2), 24-36. Retrieved from http://clelejournal.org/picturesimages-and-deep-reading-bland/

Brevik, L. M. (2016). The Gaming Outliers. In E. Elstad (Ed.), Educational Technology and Polycontextual Bridging (pp. 39-61). Rotterdam: SensePublishers. 
Burgess, М. Ø. (2016). Fra novelle til film: elevproduserte multimodale tekster. Doctoral thesis, University of Oslo, Oslo.

Chapatte, P. (n.d.). "Brexit” (C) Chappatte, The New York Times www.chappatte.com. Reproduced with permission. [image in the 2018 examination]

Choi, J., \& Yi, Y. (2016). Teachers' Integration of Multimodality into Classroom Practices for English Language Learners. TESOL Journal, 7(2), 304-327. doi: http://10.1002/tesj.204

Dahl, A. (2014). Young Second Language Learners: The Acquisition of English in Norwegian First-Grade Classrooms. Doctoral thesis, Norges teknisk-naturvitenskapelige universitet, Trondheim.

Danielsson, K., \& Selander, S. (2016). Reading Multimodal Texts for Learning - a Model for Cultivating Multimodal Literacy. Designs for Learning, 8(1), 25-36. doi: http://doi.org/10.16993/dfl.72

Education First. (2018). EF English Proficiency Index: Education First. Retrieved from https://www.ef.no/epi/regions/europe/norway/

Engebretsen, M. (2013). Visuelle samtaler: anvendelser av fotografi og grafikk i nye digitale kontekster. Bergen: Fagbokforlaget.

Godhe, A.-L. (2014). Creating and Assessing Multimodal Texts: Negations at the Boundary. Doctoral thesis, University of Gothenburg, Retrieved from http://hdl.handle.net/2077/35488

Guichon, N., \& McLornan, S. (2008). The Effects of Multimodality on L2 Learners: Implications for CALL Resource Design. System, 36(1), 85-93. doi: http://dx.doi.org/10.1016/j.system.2007.11.005

Gundem, B. B. (1989). Engelskfaget i folkeskolen: Påvirkning og gjennomslag fra 1870årene til først på 1970-tallet. Oslo: Universitetsforlaget.

Halliday, M. A. K., \& Hasan, R. (1976). Cohesion in English. London: Longman.

Hasan, R. (2001) 'Interview with Ruqaiya Hasan’ in E. Maagerø \& E. S. Tønnesen (Eds). Samtaler om tekst, språk og kultur, Landslaget for norskundervisining \& Cappelen Forlag, Oslo.

Ibsen, E., \& Wiland, S. M. (2000). Encounters with Literature: The Didactics of English Literature in the Context of the Foreign Language Classroom in Norway. Kristiansand: Høyskoleforlaget.

Jewitt, C. (2003). Re-thinking Assessment: Multimodality, Literacy and Computer-mediated Learning. Assessment in Education: Principles, Policy \& Practice, 10(1), 83-102. doi: http://10.1080/09695940301698

Jewitt, C. (2006). Technology, Literacy and Learning: A Multimodal Approach. London: Routledge.

Jewitt, C. (2008). Multimodality and Literacy in School Classrooms. Review of Research in Education, 32, 241-267. doi: http://10.2307/20185117

Jewitt, C. (2011). The Changing Pedagogic Landscape of Subject English in UK Classrooms. In K. L. O'Halloran \& B. A. Smith (Eds.), Multimodal Studies: Exploring Issues and Domains (pp. 184-201). New York: Routledge.

Jewitt, C. (2014). An Introduction to Multimodality. In C. Jewitt (Ed.), The Routledge Handbook of Multimodal Analysis (Second Edition) (pp. 15-30). London: Routledge.

Jewitt, C., Bezemer, J., \& O'Halloran, K. L. (2016). Introducing Multimodality. London: Routledge.

Knain, E. (2008). Skriving omkring praktisk arbeid i naturfag. In T. Arnesen, R. T. Lorentzen, \& J. Smidt (Eds.), A skrive i alle fag (pp. 215-227). Oslo: Universitetsforlaget.

Knox, J. (2007). Visual-verbal Communication on Online Newspaper Home Pages. Visual Communication, 6(1), 19-53. doi: http://10.1177/1470357207071464 
Kress, G. (2003). Literacy in the New Media Age. London: Routledge.

Kress, G., Jewitt, C., Bourne, J., Franks, A., Hardcastle, J., Jones, K., \& Reid, E. (2005). English in Urban Classrooms: A Multimodal Perspective on Teaching and Learning. London: Routledge.

Kress, G., Jewitt, C., Ogborn, J., \& Tsatsarelis, C. (2014 [2001]). Multimodal Teaching and Learning: The Rhetorics of the Science Classroom. London: Bloomsbury Academic.

Kress, G., \& van Leeuwen, T. (2006). Reading Images: The Grammar of Visual Design. London: Routledge.

Kruse, K. L. (2018). Bildebøker i multimodale og digitale lese- og skriveprosesser: Elevers skapende arbeid med skriving, bilde, lyd og stemme. Doctoral thesis, Universitetet i Agder, Kristiansand.

Kvåle, G. (2015). Multimodale modellar i Microsoft Word: Programvare som semiotisk ressurs. In G. Kvåle, E. Maagerø, \& A. Veum (Eds.), Kontekst, språk og multimodalitet: Nyere sosialsemiotiske perspektiver (pp. 153-169). Bergen: Fagbokforlaget.

Lund, R. (2002). A Hundred Years of English Teaching: A View of Some Textbooks. In S. Selander \& D. Skjelbred (Eds.), Fokus på pedagogiske tekster 5. Tre artikler fra norsk lcerebokhistorie (pp. 1-26). Tønsberg: Skriftserien ved Høgskolen i Vestfold.

Lund, R. (2016). Searching for the Indigenous: Urfolk i engelskverket Searching. In N. Askeland \& B. Aamotsbakken (Eds.), Folk uten land? Å gi stemme og status til urfolk og nasjonale minorieter (pp. 15-33). Kristiansand: Portal.

Lunde, K.-J., \& Skeiseid, G. (2013). "Elevene hevder . . . at de lærer mye i forberedelsestiden." Om prøveforma ved eksamen i engelsk 10. klasse: Intensjonar og realitetar. Bedre skole, 3, 40-45. Retrieved from: https://www.utdanningsnytt.no/globalassets/filer/pdf-av-bedre-skole/2013/bedreskole--3-2013.pdf

Løvland, A. (2006). Samansette elevtekstar: klasserommet som arena for multimodal tekstskaping. Doctoral thesis, Høgskolen i Agder, Kristiansand.

Løvland, A. (2011). På jakt etter svar og forståing: samansette fagtekstar i skulen. Bergen: Fagbokforlaget.

Maagerø, E., \& Tønnessen, E. S. (2010). Sosialsemiotikk - meningsskaping mellom funksjon og system. In Teoretiske tilncrminger til pedagogiske tekster (pp. 125-151). Kristiansand: Høyskoleforlaget.

Maagerø, E., \& Tønnessen, E. S. (2014). Multimodal tekstkompetanse. Kristiansand: Portal.

Michelsen, M. (2016). Teksthendelser i barns hverdag: en tekstetnografisk og sosialsemiotisk studie av åtte barns literacy og deres meningsskaping på Internett. Doctoral thesis, Universitetet i Oslo, Oslo.

Mills, K. A. (2010). Shrek Meets Vygotsky: Rethinking Adolescents' Multimodal Literacy Practices in Schools. Journal of Adolescent and Adult Literacy, 54(1), 35-45.

Nikolajeva, M. (2014). Reading for Learning: Cognitive Approaches to Children's Literature. Amsterdam: John Benjamins Publishing Company.

Nikolajeva, M., \& Scott, C. (2006). How Picturebooks Work. New York: Routledge.

Norris, S. (2004). Analyzing Multimodal Interaction: A Methodological Framework. London: Routledge.

Norris, S. (2014). Modal Density and Modal Configurations: Multimodal Actions. In C. Jewitt (Ed.), The Routledge Handbook of Multimodal Analysis (2 ed., pp. 86-99). London: Routledge.

Porter, B. (2007). “Generation Gap” cartoon. (C) Bill Porter. [image in the 2017 examination] 
Reisjø, I. A. (2006). A critical analysis of the final written exam in English in the lower secondary school. (Master i engelskdidaktikk), Universitetet i Oslo, Oslo. Retrieved from http://urn.nb.no/URN:NBN:no-15001

Rockwell, N. (1967). “New Kids in the Neighborhood”. Reproduced in this article with kind permission of the right holders, the Norman Rockwell Family Agency. [image in the 2014 examination]

Royce, T. D. (2013). Multimodal Communicative Competence in Second Language Contexts. In T. D. Royce \& W. Bowcher (Eds.), New Directions in the Analysis of Multimodal Discourse (pp. 361-390): Taylor and Francis (2006). doi: http://doi:10.4324/9780203357774

Sewell, W. C., \& Denton, S. (2011). Multimodal Literacies in the Secondary English Classroom. English Journal, 100(5), 61-65.

Silseth, K., \& Gilje, Ø. (2017). Multimodal Composition and Assessment: A Sociocultural Perspective. Assessment in Education: Principles, Policy \& Practice, 1-17. doi: http://10.1080/0969594X.2017.1297292

Simensen, A. M. (2007). Teaching a Foreign Language: Principles and Procedures (2nd ed.). Bergen: Fagbokforlaget.

Skulstad, A. S. (2009). The Need for Rethinking Communicative Competence. In R. Krumsvik (Ed.), Learning in the Network Society and the Digitized School (pp. 255267). New York: Nova Science Publishers.

Skulstad, A. S. (2018). Multimodality. In A.-B. Fenner \& A. S. Skulstad (Eds.), Teaching English in the 21st Century: Central Issues in English Didactics (pp. 257-280). Bergen: Fagbokforlaget.

Smidt, J., Tønnessen, E. S., \& Aamotsbakken, B. (2011). Tekst og tegn: lesing, skriving og multimodalitet i skole og samfunn. Trondheim: Tapir akademisk forl.

Snyder, I. (1998). Page to Screen: Taking Literacy into the Electronic Era. London: Routledge.

Stein, P. (2000). Rethinking Resources in the ESL Classroom: Rethinking Resources: Multimodal Pedagogies in the ESL Classroom. TESOL Quarterly, 34(2), 333-336. doi: http://10.2307/3587958

Tan, L., \& Guo, L. (2009). From Print to Critical Multimedia Literacy: One Teacher's Foray into New Literacies Practices. Journal of Adolescent \& Adult Literacy, 53(4), 315324.

Troelsen, S. (2018). En invitation man ikke kan afslå - analyse af afgangsprøven i skriftlig fremstilling med særligt fokus på skriveordren. Nordic Journal of Literacy Research, 4(1). doi: http://dx.doi.org/10.23865/njlr.v4.12677

Tønnessen, E. S. (2012). Digitale fortellinger som multimodal tekst. In K. H. Haug, G. Jamissen, \& C. Ohlmann (Eds.), Digitalt fortalte historier: Refleksjon for læring (pp. 61-75). Oslo: Cappelen Damm akademisk.

Udir. (2013). English subject curriculum [translated version]. Retrieved from http://data.udir.no/kl06/ENG1-03.pdf?lang=eng.

Udir. (2018/2019) Fagfornyelsen. Retrieved from https://www.udir.no/laring-ogtrivsel/lareplanverket/fagfornyelsen/.

Unsworth, L. (2014). Multimodal Reading Comprehension: Curriculum Expectations and Large-Scale Literacy Testing Practices. Pedagogies: An International Journal, 9(1), 26-44. doi:10.1080/1554480X.2014.878968

van Leeuwen, T. (2005). Introducing Social Semiotics. London: Routledge.

van Leeuwen, T. (2017). Multimodal Literacy. Viden om Literacy, 21, 4-13.

Vygotsky, L. S. (1986). Thought and Language (A. Kozulin, Trans. A. Kozulin Ed.). Cambridge, Mass: MIT Press. 
Waallann Brown, C., \& Habegger-Conti, J. L. (2017). Visual Representations of Indigenous Cultures in Norwegian EFL Textbooks. Nordic Journal of Modern Language Methodology, 5(1). http://journal.uia.no/index.php/NJMLM/article/view/369/371

Walsh, M. (2008). Worlds have Collided and Modes have Merged: Classroom Evidence of Changed Literacy Practices. Literacy, 42(2), 101-108.

Yi, Y., King, N., \& Safriani, A. (2017). Reconceptualizing Assessment for Digital Multimodal Literacy. TESOL Journal, 8(4), 878-885.

Ytreberg, L. (1993). Engelsk i grunnskolen. Oslo: Tano.

Ørevik, S. (2012). From Essay to Personal Text; the Role of Genre in Norwegian EFL Exam Papers 1996-2011. Acta Didactica Norge, 6(1), 1-21. doi: http://dx.doi.org/10.5617/adno.1090

Ørevik, S. (2019). Mapping the text culture of the subject English: Genres and text types in national exams and published learning materials. Doctoral thesis, University of Bergen, Bergen.

\section{Examinations}

From the Norwegian Directorate for Education and Training (Udir), the following documents from years: 2014, 2015, 2016, 2017, and 2018 have been examined and quoted in this article:

- Examination guidelines

- Preparation material websites

- Examination (Centrally given examination after year 10 for students and for adult participants and external participants. In Norwegian: Sentralt gitt eksamen etter 10. trinn for elevar/elever og for vaksne/voksne deltakarar/deltakere og privatistar/privatister.)

- Assessment examples (Vurderte eksamenssvar)

- Pre-examination reports (Forhåndssensur) 